\title{
The Impact of Arabic Orthography on Literacy and Economic Development in Afghanistan
}

\author{
Anwar Wafi Hayat \\ Department of Economics, Kabul University, Kabul, Afghanistan \\ Email address: \\ Wafihayat786@gmail.com \\ To cite this article: \\ Anwar Wafi Hayat. The Impact of Arabic Orthography on Literacy and Economic Development in Afghanistan. International Journal of \\ Education, Culture and Society. Vol. 4, No. 1, 2019, pp. 1-12. doi: 10.11648/j.ijecs.20190401.11
}

Received: October 15, 2018; Accepted: November 8, 2018; Published: January 31, 2019

\begin{abstract}
Currently, Pashto and Dari (Afghan Persian), the two official languages, and other Afghan languages are written in modified Arabic alphabets. Persian adopted the Arabic alphabets in the ninth century, and Pashto, in sixteenth century CE. This article looks at how the Arabic Orthography has hindered Literacy and Economic development in Afghanistan. The article covers a comprehensive analysis of Arabic Orthography adopted for writing Dari and Pashto, a study of the proposed Arabic Language reforms, and research conducted about reading and writing difficulty in Arabic script by Arab intellectuals. The study shows how adopting modified Latin alphabets for a language can improve literacy level which further plays its part in the economic development of a country. The article dives into the history of Romanization of languages in the Islamic World and its impact on Literacy and economic development in those countries. Romanization of the Afghan Official languages and its possible impact on Literacy, Economy, and Peace in Afghanistan is discussed. Proposed Latin-based Alphabets are introduced for Dari and Pashto languages and factors that may facilitate or hinder the implementation of a Latin-based script in Afghanistan are explained at the end of the article. Romanization, referred to in this article, means converting to Roman script, also called Latin-based script, the alphabets of a language currently written in orthography other than the Latin.
\end{abstract}

Keywords: Romanization, Arabic, Pashto, Dari, Literacy, Orthography, Script

\section{Introduction}

The Arabic script, which is also called the alphabets of the Quran, is the writing system used for Arabic language and for different languages of the world, especially languages of the Muslim speech communities. Arabic Script has 28 total letters with numerous diacritic signs used to represent the vowel sounds. The script is cursive and most of the letters change form when they are combined to write a word. The current Persian Script, which is a modified form of Arabic orthography, added four more letters to the Arabic alphabets and created 34 letters alphabets with 9 diacritic marks for Persian used in Iran and Afghanistan. The Pashto, which also uses a modified Arabic script, added more letters to it creating a 45 letters script with four diacritics.

The spread of Islam brought with it the Arabic language and alphabets to the non-Arab world. After conversion to Islam, it was obligatory for Non-Arab communities to learn the Arabic script for reciting the Holy Quran and performing other religious duties. The Umayyad Dynasty (661-750) declared Arabic as the official language of the Islamic Caliphate in seventh century CE. [1] Before the reign of Abd al-Malik (685-705), Coptic, Greek, Latin, Persian and other languages of Non-Arab communities had official status in certain regions. Muslim communities under Islamic Caliphate in parts of Middle East, Central Asia, North Africa, Western Europe, and India, were obliged to learn and use the Arabic language and script because it was introduced as the language of the Holy Quran. Non-Muslims had to learn it because it was the language of Administration. As a result of the religious and political influence of Arabic, Non-Arab communities modified the Arabic alphabets to create their own writing systems replacing their previous orthographies.

Apart from Persian in Iran and Afghanistan, Arabic script was also used for writing Tajik and Turkic languages of Central Asia such as Uzbek, Kyrgyz, Kazak, Azeri, and Turkmen. In the 1920s these languages changed their alphabets from Arabic to Latin. Later, Latin was replaced by Cyrillic in 1938. Cyrillic was replaced by Latin again in the 1990s in most of the Central Asian countries after the 
influence of Russia declined in this area. Tajikistan still uses Cyrillic to write the Tajik language. Similarly, Turks had modified Arabic script according to their own language needs which was replaced with Latin in the 1920 s by Mustafa Kemal Ataturk as part of widespread reforms. [2] The Turkic communities living in Afghanistan, Iran and China; Kazakhs, Uzbeks, Turkmens, and Kyrgyz, for example, still, use the modified Arabic scripts for writing.

Similarly, in Asia and Africa, the Arabic script was adopted for various Hindustani and African languages. Apart from Africa and Asia, languages in other parts of the world like Europe, Caucasus, and the Middle East, have also been using Arabic Script out of which several languages have adopted the Latin script now.

\section{Reading Difficulty in Arabic Script}

\subsection{Vowel Sounds}

Arabic Script does not have separate letters to indicate the vowel sounds in writing. Vowel sounds are differentiated by the use of diacritic signs which are called Tashkeel Harakātshort vowel letters for the phonetic purpose, written above or below the alphabets. These short vowel signs are not written in usual publications and are restricted to the Holy Quran because one has to recite it with the exact pronunciation. It's also used in material written for the new learners of the Arabic language. In earlier versions of the Holy Quran, the diacritic signs were not written.

Without the diacritic vowel sounds, it is difficult to read texts correctly in the Arabic script if the reader lacks a prior knowledge of the words used in a sentence. In Dari and Pashto, the short vowel signs are also not written which has made reading a confusing and complex task. The reader, for instance, has to guess the pronunciation of a word according to the context of the sentence and must have prior knowledge of its pronunciation. Without using diacritics, the majority of words in Dari and Pashto with different meanings and pronunciation are written with the same spelling. The only way to write or pronounce them correctly is the use of diacritics which is a tedious and erroneous task if one chooses to write them. The following words, which are written the same, can be pronounced in more than one way, with completely different meanings; سرور can be read as Sarwar, a male name in Afghanistan, also as Sorur which means joy. Because it is written without writing the short vowels in Dari and Pashto, therefore the reader is confused whether to read it with a, or o vowel in his/her mind. Other examples can include دين Pronounced as Deen-religion. Or as Dayn - خون. pronounced as Khog-sweet, and also as Khwəg-hurt. Pronounced as Gul - flower. Also as Gil mud.

The aforementioned words, if written in a sentence, may get easier to figure out which word the writer wanted to use by letting the reader know the context. But it doesn't save one from making a reading mistake. The reading difficulty worsens when it comes to unfamiliar words. For instance, the newscaster of a famous private TV channel in Kabul pronounced the name of one of the districts كثنده as Kushinda which means killer, instead of Kishindeh even though the context here is known as the word Wolaswaly is written with it indicating it is the name of a district. Both Koshinda and Kishindeh are written exactly the same in Dari due to the absence of the short vowels o and i. Similarly, a prominent Pashto channel's newscaster in Pakistan pronounced the name of the Northern province Balkh of Afghanistan, as Balakh, due to his unfamiliarity with the pronunciation of this word and because it is written without the short vowel a in Dari and Pashto.

This confusion is not limited to context or lack of prior knowledge. Even sentences, for which a reader might have prior knowledge of the meanings and pronunciations of words, will cause trouble. For instance, the sentence written in Dari ليلى قالين را ميبرد can have three different meanings and can be three different sentences written in different tenses. The sentence can be read as Laila qalin ra mibarad-Laila carries the carpet. Laila qalin ra miburd-Laila used to carry the carpet. Laila qalin ra miborad - Laila cuts the carpet.

It's not only difficult for students to comprehend the written text in books without making mistakes but also newscasters, politicians, and government officials face embarrassment while delivering public speeches. Recently, a minister of the Afghan Cabinet made hilarious reading mistakes while delivering a speech about the Afghan Post which became viral on social media, receiving huge criticism from Afghans.

When it comes to Dari and Pashto, they are vowel based languages while Arabic is consonantal. The Semitic and consonantal nature of Arabic has made it difficult for Pashto and Dari to fit in the Arabic Script. For instance, Pashto has 7 vowels (and in some of its accents, more than 7). When written in Arabic Script, the vowel sounds are not properly pronounced. For example, the vowel sound s (ə) pronounced as $\mathrm{i}$ in English word bird, is not properly represented by the current Pashto alphabets. Even though this vowel is denoted in the current Pashto script by adding a diacritic sign Hamza

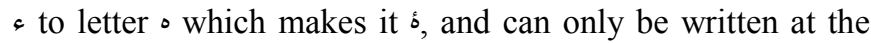
end of a word to denote this vowel but the fact that hamza is a diacritic sign, like other diacritics it is also not written in majority of the Pashto texts and is always written as o which is pronounced as "a" resulting in confusion. For instance, the verb Pashto word for Came in these sentences هغه راغله (She came) pronounced as Hagha raaghla and هغوى راغله Haghoy raaghla (They came) are pronounced by two different vowels while pronouncing it but in the written form only one vowel $\mathrm{a}$ is used leaving no difference between the verbs used for She and They, which are two different scenarios in Pashto. The correct forms of the verb would be raaghla for She, and raaghlo for They ( $\partial$ is pronounced as $i$ in shirt). Apart from that, there is no letter in Pashto, or the Arabic script to write vowel $\partial$ in the middle of a word except for using a diacritic sign. For example, the word تل which means Always in Pashto is written as Tal but pronounced as Təl. There is no way to differentiate the aforementioned word from تل which 
means bottom. Both words Tal and Tal have the same spelling but different pronunciation and meanings in Pashto. There are hundreds of such words which the current orthography has no solution for, even if the diacritics are added. Vowel (ə) is also present in the Turkish language represented by a dotless 1 which the Ottoman Turkish could not incorporate in its Arabic based alphabets. Vowel 1 and i, in Turkish words Altı (six) and Yedi (Seven) were both يدى and آلنى respectively which lead to the mispronunciation of these words.

The sounds $\mathrm{o}, \mathrm{u}$ and oo are not differentiated while in writing. The word توره can have two different pronunciations and meanings. Toora which means Sword. And Tora-Which means black (for words of feminine gender). The absence of the aforementioned vowels in writing might have been the reason for shaping the accent of Peshawar Pashtuns; they pronounce the words كول as Kol (doing) the right pronunciation of which is Kawəl.

Same is the case in Persian or Dari as it is called in Afghanistan. For example, words like رنجور, مزدور which used to be pronounced as Ranjwar, Muzdwar and Faravahar respectively, have lost their correct pronunciations to Ranjoor, Mazdoor and Farohar because when written in Arabic script they can be read either way.

\subsection{Similar Letter Shapes}

Arabic Orthography is based on a limited number of alphabet shapes, maximum eight or nine basic shapes; ، ب، د، ر، س، ص، ط ، ع، ف denote the rest of the Arabic alphabets by adding little dots over or below them.

For instance, letters $ت$ and $ث$ are the modified forms of letter $\varphi$. The same letter was further modified in Pashto and Persian scripts creating more letters. Persian, for example, modified it for letter $\uplus(\mathrm{P})$ and Pashto for letter $\uplus(\mathrm{T})$. Thus this one letter $ب$ (B) was modified to create four more letters . The extreme case can be the modification of letters $ح$ and $\checkmark$ in Pashto orthography. Letter $ح(H)$ is modified to achieve 5 more letters- $\dot{\tau} \dot{\tau} \dot{\tau}$ ج (with and $\dot{\tau}$ already present in Arabic and Persian modified from $\tau$ ) and letter $ى$ to achieve بs letters having almost similar shapes with different sounds. Same is the case with other letters slightly modified for completely different sounds. For the human mind to differentiate various sounds by a slight difference in the alphabet is a difficult task and prone to error. Especially when it comes to the letter $s$, it is always full of confusion in reading and writing. In Pashto, for example, the use of these 5 types of $\checkmark$ is sometimes very limited. In informal writing, and some formal too, only one type of $\varsigma$ is usually used and the reader has to guess it according to the context or prior knowledge of the word. In Dari, there is only one type of $\checkmark$ used for different vowel sounds and can be distinguished by guessing. For instance, the sentence كى آمد؟ can have two different meanings. Ki amad?-Who came? And Kay amad?-When did he/she come?
In early versions of the Holy Quran, the dots were not used to differentiate the letters from each other. Because the Holy Quran was memorized by a large number of Arab Muslims, they had no problem in figuring out the correct pronunciation. However, as the spread of Islam widened and non-Arab communities embraced Islam, the problem of wrong pronunciation resulted in writing the Holy Quran with diacritic signs and dots to differentiate letters and correct pronunciations.

\subsection{Changing Shapes}

Because Arabic Script is cursive, when combined to write a word, unlike Latin, most of the letters change its original form depending on its position at the start, middle or the end of a word. To write the word Tahqiq (research) for example, the letters ت ت ح ق ى ق changed forms as تحقيق. The similarity of the alphabets when combined to form a word make it heavy for the mind of the reader to read the text easily. For instance, if one would want to write Takhfif (meaning discount) it would look like تخفيف (Try to see the similarity of the two words تخفيف تحقيق).

\subsection{Same Sound, Different Letters}

As it is difficult to read Arabic script, in the same manner, writing can be tougher. When Arabic script was adopted, letters of the Arabic script which do not represent any phonemes in Dari and Pashto, migrated into these languages. This extra letters created the problem of different letters with the same sound thus making the spelling intensely difficult. If one has to write a word, she/he must have memorized the spelling of majority of the words to write them correctly. For example, these letters have the same sounds in Dari and Pashto but different shapes and are used to write various words; b ، w for T, ضfor Z. To write the words Sahar, Sihat, and Samar in Dari and Pashto, three different letters are used to represent the letter S in these words - سحر(Sahar) is written with س صـ, Sihat صن ص is written with and Samar is with ثرت a person to master the Dari and Pashto spellings, he/she has to memorize all three spellings as there are no rules which can differentiate the usage of these letters. Same is the case for other letters. However, in Pashto and Dari, deviations have been seen in writing the same phonic words with different letters. For instance, the صلح (Peace) is no more written with the Arabic letters $ص$ and $ح$ instead it is written as سوله. And in Persian اطاق (Room) is now written as اتهاق. This deviation can be seen in Pashto for more words than in Dari.

\section{Romanization in the Muslim World}

\subsection{The Turkish Example}

The most famous and successful example of Romanization is the example of Turkey. Turkey switched its alphabets from Arabic to Latin at the end of the 1920s introducing a 29 letters Turkish orthography through a law passed by the 
Grand General Assembly of Turkey as part of the reform movements started by Mustafa Kemal Ataturk. Along with other benefits and goals behind its implementation, the new Turkish alphabets were easy to read, write and learn and as a result boosted literacy rate, [3] and facilitated the social, cultural and economic development of the Turkish state. [4] However, the only goal of the alphabet change was not the literacy boast or economic stability. In order to understand the complete scenario and the goals of Mustafa Kemal Ataturk behind the Alphabet reform, it's important to look into the various reform movements started by him.

When the Ottoman Empire collapsed after World War I, the Western Powers attacked Anatolia-the modern day Turkey. The Turkish Nationalist Army under the leadership of Mustafa Kemal Ataturk, successfully expelled the western powers in 1922, establishing the Republic of Turkey. Mustafa Kemal, being the first President of the Turkish Republic, started various socio-religious and political reform movements to transform the Turkish society. Through his reforms, Ataturk aimed at shaping the ideologies of Turks in a secular way. He wanted a nationalist Turkish nation which would be more Turkish, secular and European in behavior and thought. For this to achieve, Ataturk wanted the Turks to turn their back on their religious past and to look in the direction which he wanted them to see. Therefore, he abolished the administrative institutions left by the Ottoman Empire replacing them with the Western systems. [5]

His reforms were based on three aspects of change; Secularization, Westernization and Nationalization. [6] The people of Turkey had their roots in the Islamic Civilization and had adopted Islamic ideologies, beliefs and the way of life. He believed that Turks should resemble the West in all respects even the outfits. [7] What Ataturk wanted was a fully transformed Turkish society, dropping everything that attached them to Arabs and Islamic Civilization. In order to implement his reforms to bring the Turkish nation out of their Islamic past, he looked upon the Caliphate as a big hurdle. Therefore, he abolished the Islamic Caliphate through a bill passed by the Grand General Assembly in 1924. He also abolished the educational institutes established by the Ottoman Empire including religious schools along with the Ministry of Evkaaf (religious affairs) and brought religious institutions in Government control. [8] Because westernization acted as an ideal model for him, the phenomena of widespread nationalization and secularism in neighboring Europe, were the best options to drive out the remnants of the Ottoman Past from the country. Therefore, he decided that religion should be separated from the state. [9] The people of Turkey, which had lived under the influence of Islam for centuries, looked down upon the reforms and secularism and started to resist the reform movements but the authoritative policies of Ataturk subdued every effort against the reforms. [10] Finally, in 1928, he was successful to pass a bill turning the Turkish Government into a legally Secular state.

After proclaiming Turkey a secular state, he paved the way for cutting every link that would tie the nation to its Islamic roots. He had to get rid of the Arabic language and script which had been ruling the Turkish education system and culture. He thought that Arabic and Persian influence on the Turkish language, or Ottoman Turkish, which was thus called, and the Arabic alphabets were preventing Turks from becoming a modern and developed nation. Ottoman Turkish vocabulary was a mixture of Arabic, Persian and Turkish words which had a wide range of loan words and expressions borrowed from Arabic and Persian. [11] Ottoman Turkish was written in Arabic script and the Arabic alphabets were seen as the religious identity of the Turkish nation which prevented Ataturk from shaping the nationalist ideology. Apart from that, the Arabic Script could not incorporate the Turkish vowels correctly.

Therefore, he started language reforms to purify the Turkish language by replacing Arabic and Persian words with original Turkish words and dropping the Arabic script in an attempt to completely remove it from the minds of Turks. [12] A commission was formed by Ataturk to work on the Alphabets reforms in May 1928. The commission, along with other suggestions, suggested that a modified Latin orthography was the best option for writing Turkish. The commission accepted the new 29 letters Turkish alphabets in Latin which were approved by the Grand General Assembly in November 1928. The use of Latin alphabets became compulsory in 1929 in Public communication. [13] It was made unlawful to write Turkish with Arabic letters. [14] The teaching of Arabic and Persian as foreign languages was prohibited. [15] Thus, Ataturk with his language and alphabets reform made Turks unlearn the Alphabets of their faith, built huge walls of reforms and prohibitions between them and their Islamic Past and opened doors to the western culture and society.

\subsection{The Central Asian and South East Asian Countries}

In Central Asia, Arabic Script was used to write Tajik, Kazakh, Turkmen, Uzbek, Kyrgyz and Azeri languages till the 1920s. Tajikistan, Kazakhstan, Turkmenistan, Uzbekistan, Kyrgyzstan, and Azerbaijan had to drop the Arabic alphabets for their languages and instead adopt the Latin script. By changing the Script to Latin, Lenin wanted to create literate Muslim Socialist Societies in Central Asia paving the path for weakening the influence of the rest of Islamic world on them. [16] The Soviet establishment believed that Latin was the favored medium of Literacy rather than Cyrillic. [17] Among the reasons that Latin was preferred over Cyrillic for Central Asian countries was the simplification of Literacy and, as per Soviet Commissar of Enlightenment Anatoly Lunacharsky, Lenin believed that eventually, the Russian language will also adopt Latin script dropping the Cyrillic. Therefore, attempts were made to Romanize the Russian Alphabets by assigning a Commission in January 1930. The commission came up with a Romanized Russian alphabet in mid-January 1930. However, the Romanization of the Russian language was stopped by General Secretary Joseph Stalin.

The issue of selecting a perfect orthography among Arabic, 
Latin and Cyrillic, for Turkic languages of Central Asia-Uzbek, Turkmen, Kazakh, Kyrgyz and Azeri, was already being discussed by the leadership of these countries. For instance, in 1921, the Uzbek Language and Orthography Congress proposed the Latin alphabets for the Uzbek language. The proposal was not welcomed by the conservatives and the Congress of Uzbekistan. The religious Past of Uzbeks was not ready to break its ties with the Islamic world. However, in 1924, after becoming a member of the USSR, Uzbek leadership, under the influence of Russia, and in order to become closer to the Turkic people, had to opt for the Latin alphabet. [18] In 1926, consequently, a resolution of Latin alphabets was proposed at the Baku Turkological Congress for Turkic languages. After the Baku Congress, a Committee was established for new Latin Alphabets for Turkic languages declaring the switch from Arabic to Latin.

By the end of 1920s Tajikistan, Azerbaijan, Uzbekistan, Turkmenistan, Kazakhstan, and Kyrgyzstan had adopted the Latin alphabets. After adopting the alphabets, later the use of Arabic script was prohibited. For instance, in 1929 publications in Arabic script were completely prohibited in Azerbaijan. [19] Similarly, like Turkey, a great number of Arabic and Persian expressions and words were replaced by Turkic and Russian words in Uzbek, Turkmen, Azeri, and other Turkic languages in a process of Russification.

The use of Latin script continued till the end of the 1930s. However, as Turkey had also adopted the Latin alphabet, it had played an important role in bridging the gap between Turkey and the Turkic countries of Central Asia which had made the USSR concerned of pan-Turkic influence over these countries. Stalin wanted to create internal unity among the USSR countries and a unified Soviet Identity. In 1939, he dropped the Latin alphabet and implemented Cyrillic instead to decrease the Turkish and western influence on Muslim Turkic countries of Central Asia. The Latin alphabet was viewed as a symbol of Western Imperialism. In order to achieve a strong and centralized USSR, the use of Cyrillic was seen as a bond to unite the people of different faiths, origins, and languages together. The expressions of faith were strictly prohibited and Russian identity was preferred over local. Even though the switch from Latin alphabet was resisted by the Turkic nations which resulted in arresting and killings of several people, however, Cyrillic was the only option for these countries under Stalin. [20]

The use of Cyrillic continued till the 1990s. However, as the Soviet influence started to decrease in Central Asian countries, after declaring independence from Russia, most of these countries decided to drop Cyrillic going back to the Latin alphabets. The use of Russian as the Official language was also dropped and restricted in most countries. The fact that education, modernism, and technology flourished in the lap of Latin alphabets, the Central Asian countries showed a greater inclination towards re-adopting this script. Thus, in 1991, Azerbaijan passed a law to re-adopt the Latin script replacing Cyrillic, in an attempt to go away from Russian influence towards its Turkic roots. Similarly, Cyrillic script was used to write the Uzbek language in Uzbekistan till 1992 and till 1993 in Turkmenistan to write Turkmen. After getting their independence, these countries declared to adopt Latin which was gradually implemented throughout the years till this day, however; Cyrillic is not fully replaced and is still used in publications.

In case of Kazakhstan, the President decreed in 2017 that new Latin alphabets should be created paving the way to drop the Cyrillic script. However, Russian influence still plays a role in slow switching from Cyrillic to Latin. For instance, in Kyrgyzstan and Tajikistan, Cyrillic is still used to write Kyrgyz and Tajik languages and the possibility that these countries will switch to Latin is seen as dependent upon their close ties with Moscow. In Tajikistan, however, the influence of Iran could also be considered in making the decision to switch the alphabets due to the same languagePersian in both countries. In Azerbaijan, for instance, when discussions started about dropping the Cyrillic alphabets and choosing a perfect orthography for Azeri language from Latin, Cyrillic, and Arabic script, the Iranian clergymen distributed leaflets in Azerbaijan persuading Azeri Muslims to choose Arabic script as it was the alphabet of the Holy Quran. The Central Asian Republic of Tatarstan, which is a federal unit under the Russian Federation, like other Turkic countries, had also switched from Arabic to Latin in the 1930s and from Latin to Cyrillic in 1940s to early 1990s due to the policies of USSR. In the 1990s and early 2000s, Tatarstan intended to switch from Cyrillic to Latin. However, in 2002, after the Russian Parliament made Cyrillic the only script for all official languages, in an attempt to counter ethnonational separation and political agitation, Tatarstan had to discontinue the use of Latin as its official script. However, the Latin script can still be used as an option along with Arabic script but the use of Cyrillic is compulsory in official documents.

\subsection{Africa and South Asia}

The South East Asian Muslim countries of Malaysia, Indonesia and Brunei Darussalam used a modified Arabic Script called Jawi to write the Malay language which has official status in Malaysia, Singapore, Brunei, and Indonesia. Apart from the aforementioned countries, Jawi script was also used in Southern Thailand and Muslim areas of the Philippines for the Malay language, and for Cham language in Cambodia. Jawi script was adopted with the arrival of Islam in this region. Prior to Arabic script, Malay was written in Pallawa, Kawi and Rencong Alphabets. In the early $20^{\text {th }}$ century, Latin alphabets were developed for Malay language orthography called the Rumi Script. Rumi script is now used as the official script of Malaysia, Indonesia, Singapore, and Brunei. However, Jawi script is still official along with Latin script in Brunei and its use is maintained in parts of Malaysia, Indonesia, Thailand, and the Philippines. In Indonesia, even though Latin is the only official script, the use of Jawi is still not stopped and is used in Malay populated areas. The Patani Malay living in southern Thailand uses Jawi for religious purposes and a Thai based 
script for education. [21] Similarly, Kelantan population in Malaysia uses the Jawi script for religious purposes.

In South Asia, the Arabic script was used to write Urdu, Balochi, Punjabi, Kashmiri, Sindhi, Dogri, Malayalam and other regional languages spoken in different areas of Pakistan, India, Bangladesh, Burma, and Sri Lanka. In the 1920 s and 30s, linguistics in India, influenced by the simplicity of the Latin alphabets suggested a Roman-based script in India for writing various Indian languages. However, local scripts were seen as a sign of nationalism while Roman alphabets, a symbol of Imperialism, therefore, developing a Roman-based script for Indian languages was not considered.

In Africa, the Arabic script has been used to write different African languages. However, languages like Somali, Swahili, Malagasy, Nubian and the West African languages Hausa, Fula, Mandinka and Wolof along with several others, have officially switched from Arabic alphabets to Latin.

\section{Script and Literacy}

As it can be seen from Ataturk's alphabet reform and Lenin's adoption of Latin for Central Asian countries and his inclination toward replacing Cyrillic with Latin script, there exists an important link between Orthography and Literacy. In this part, I will aim at explaining how certain scripts used for writing a language can boost or hinder Literacy by looking into the Turkish and the Central Asian examples.

A recent study carried out in the University of Haifa, published in Neuropsychology journal, shows that reading acquisition in Arabic is harder than in English due to the complex nature of the script. Prof. Zohar Eviatar and Dr. Raphiq Ibrahim, in a series of studies, have come to the conclusion that the reading difficulty in Arabic is due to the complexity of the Arabic script as most of the sounds of the Arabic alphabets are distinguished by very slight differences of diacritics such as Tashkil Harakat and dots so much similar to each other that the mind of the reader has to take more time to figure them out as compared to the English script. The study supports the findings that these similarities overburden the brain which results in slow processing and makes reading Arabic text difficult.

In regard to the absence of vowels and diacritics and the uncertainty it creates in the mind of readers, Baluch and Shahidi studied the ambiguity arising from it. [22] Persian children with mean age of 8.4 years were tested to name words with consonantal spellings and words with vowel letters spellings. The study showed that the degree of errors in reading words with consonantal spellings was greater than that of words with vowel letters spellings. Similarly, children took more time to read words with consonantal spellings than that of vowel spellings. In the same manner, Baluch (1990, 1993) found that the result of the aforementioned study conducted on adult Persian children was the same. A similar study was conducted by Abu-Rabia (1997) with the finding similar to that of Baluch. He tested the effects of vowels on reading accuracy of poor and skilled Arab readers by making them read vowelized and un-vowelized text and word naming in Arabic. His study found that the use of vowels played an important role in facilitating word recognition in Arabic Orthography.

In relation to the similarity of letters in Arabic Script, Azzam, R (1989) concluded that Arab children faced difficulty in distinguishing words from each other and could not differentiate easily consonantal and vowel letters. Similarly, she reported difficulty faced by Arab children in figuring out the changing shapes of letters when combined to form a word.

Considering the complexity of the Arabic orthography, several proposals by Arab intellectuals for reforming the Arabic language and script were initiated in the past. These included proposed solutions for making the Arabic script easy to read by incorporating the Tashkeel vowel marks (the diacritics) into written words and reducing the forms of letters in writing by Egyptian Scholars Ali al-Jarem, Mahmoud Taimour, and Elias Akkawi. [23]

The Cairo Academy of Arabic language, through an international contest with a prize of 1000 Egyptian pounds, called for proposals from the Arab world for simplifying the Arabic writing system, in 1945. [24] Till March 1947 the academy received about 200 project proposals for simplifying the Arabic writing system. For five years, the academy, through an assigned commission, studied the 200 projects received through the contest but found that none of the proposals met the requirements of the contest. However, in 1959, a sub-commission was formed and only a project that proposed a typographical simplification of Arabic was approved in 1960 .

Nasri Khattar, a Lebanese born artist, proposed a modified Script for printing purposes which he called Unified Arabic (Al-Abjadiah al Muwahhadah) in 1947. [25] According to Khattar the various changing shapes of Alphabets resulted in reading and writing difficulty. His Unified Alphabets reduced the letterforms to 30 from 150 . His proposed letters could be written separately even in the written text. The proposed alphabets need not be joined together when written and did not change shape. [26]

Abd Al Aziz Fahmi who served as the chairman of Writing and Grammar Committee for the Arabic Language Academy of Cairo, in 1944, supporting the views of other Egyptians scholars such as Ahmad Lutfi As Sayid, Muhammad Azmi, and Salama Musa, suggested to replace the Arabic script with Latin script in order to make it easy and simple. [27] Earlier, in 1880 and 1890, calls for Romanizing the Arabic alphabets were initiated in Egypt by two directors of the Egyptian National Library. [28] Another proposal for Romanization of the Arabic language was presented by the Lebanese Author Sa'eed Aql in his book Al-Khumasiyyat, published 1978 in Beirut. Other scholars like Ahmad Lakhdar Ghazal, Moroccan scholar, Mohammed Said al Saggar from Baghdad, also aimed at simplifying the Arabic script. [29] Apart from the the Arabic language, considering the problems with the Arabic script, many Iranian Scholars like Mirza Fath Ali Akhondzadeh, Ahmad Kasravi, Sadiq Hidayat 
and Kourosh Safavi have proposed to adopt Latin-based alphabets for Persian. However, these proposals have resulted both in proponents and opponents of Romanization in Iran.

During the $90 \mathrm{~s}$, due to the use of modern technology and because Arabic script along with other Non-Latin scripts was not supported in modern devices, internet sources, and computers, the Arab speech communities started to use the English Alphabets to write Arabic in different internet platforms, social media, text messages and chat. The English alphabets along with numbers were used to describe different letters of Arabic alphabets thus developing a Romanized script for the Arabic alphabet which is now called Arabizi. [30] Arabizi is a combination of two words; Arabic and "Inglizee" which is an Arabic word for English. Till today, the use of Romanized Arabic, or Arabizi, is widespread in the Arab world even though modern devices now support the use of non-Latin scripts. [31] Similarly, the term Finglisi, or Finglish is used for Latinized Persian used by the Farsi speaking communities in their communications across the internet.

When it comes to Technology, Arabic script is not loved by computers and different applications. The programming languages do not understand Arabic code. Besides a lot of efforts, Arabic alphabets are still not used for web addresses on a wide scale.

In contrast to Arabic Script, the Latin Script has several beneficial qualities. It is not cursive and does not have initial, middle, final or individual shapes for alphabets, which means the reader does not have to put extra effort and brain stress to read words written in this script correctly. More ever, having separate letters for different vowels, Latin script saves one from ambiguities of different vowel sounds while reading. Technology flourishes in the lap of Latin script and the majority of the world population can read it.

From the above explanations, it can be concluded that the Arabic orthography currently used in Afghanistan is a source of unnecessary confusion and a hindrance to literacy. When Ataturk decided to switch Turkish Orthography from Arabic to Latin, he had in his mind an economically developed and literate Turkish nation which could compete with European countries in education, science, and technology. His efforts resulted in a positive step towards achieving his goals. For instance, the literacy rate in Ottoman Turkey was as low as $10 \%$ while after implementing the Latin alphabets the Literacy rate of Turkey boasted from $10.6 \%$ in 1927 to $22.4 \%$ in 1940 , and $30.5 \%$ in 1945. [32] The low level of literacy in Ottoman Turkey was believed to be due to the difficulty in learning the Arabic script. [33] According to Barbara Kellner-Heinkele, a Berlin-based expert in Turkic languages and history, by modernizing Turkish language and legal systems, Turkey established its position as an economic power. The Turkish economy is believed to be one of the world's fast-growing economies.

Similarly, when Lenin decided that Central Asian countries should choose script among Arabic, Latin, and Cyrillic, he chose Latin. Lenin believed, as mentioned above, that in order to create Socialist Muslim societies, Muslim population had to come out of the widespread illiteracy. He looked at the
Latin alphabet as the best option to achieve his goal of literate societies due to the simple and dynamic nature of the script. Even though Latin was dropped later in favor of Cyrillic by Stalin, however, understanding its advantages, most of the Central Asian countries switch back to it after getting their independence from USSR in the 1990s. Today the literacy rate in these countries is more than $99 \%$. [34]

The widespread illiteracy in Afghanistan is a source of insecurity, economic backwardness, and extremist mindset. Afghanistan is struggling hard to improve literacy; however, there are many factors which are slowing this process. For instance, the religious extremist groups active in many parts of the country are against modern education, especially for the woman. Every year a large number of schools are closed due to security threats. Militants will not spare any chance to blow up or burn a school and kill its teachers. They are also threatening the parents of children to stop them, especially girls, from going to school. Apart from the militants, a large number of Afghans believe that education is not necessary for girls and not aware of the importance of education and the dangers of illiteracy, they are not very serious even about sending their male children to school. Instead, they will prefer sending them to Madrassa-religious education. Some will not send them to school due to poverty and instead send them to work. As we can observe there are various challenges faced by Afghans to become literate citizens. Keeping in mind the abovementioned conditions, can Afghanistan manage such a complex and difficult Orthography? Afghans are already paying a high price for getting educated. Therefore, a simple and easy to learn script will have huge effects on literacy acquisition. It will not only decrease the literacy acquisition time but will also help Afghan students in improving their creative skills by investing their time in critical thinking instead of just memorization. Adopting a Latin script will not only improve literacy, but it will also bring economic development with it, in the long run.

\section{Literacy and Economy}

"If all children in low-income countries left school knowing how to read then 171 million people could move out of poverty." -World Literacy Foundation, Final Report, 2015.

Illiteracy and economic backwardness are interrelated. Countries with low literacy rates have the highest social and economic problems. The World Literacy Foundation in its final economic report 2015 has estimated the cost of illiteracy in social and economic terms explaining how illiteracy pushes countries into poverty. The report states that illiterate people are faced with the problem of poverty, limited employment opportunities, and income generation and higher chances of poor health, crime, and charity. Crime estimates of various countries of the world, as per the report, show that reading and writing skills of $60 \%-80 \%$ of the prisoners are below basic level with high chances of returning to crime in illiterates when they are released. Similarly, illiterates can achieve 30\%-42\% fewer earnings than literates. Illiteracy also affects the productivity and 
profitability of businesses and decreases wealth creation opportunities for individuals and businesses. According to a Survey, $70 \%$ of the employees revealed that organizations made noticeable cost savings by providing literacy and language training to their staff. [35]

The report states that the economic cost of illiteracy in Afghanistan is US\$ 0.10763 billion per year. One may argue in terms of more than $99 \%$ literacy rate and its relation to the economy in Central Asian countries. However, could these countries bear the high cost of illiteracy in US dollars each year had the literacy rate been lower there? Apart from that, would these countries be as peaceful and civilized as they are today? One could imagine how poor these countries would be in case they had low literacy rates. For a poor country like Afghanistan, making literacy easy and education accessible will play an important role in achieving economic prosperity. It is also referred to the UNESCO, estimates state that raising the average level of education of the adult populace per year, will result in a corresponding increase of $3.7 \%$ in long-term economic growth and a $6 \%$ increase in per capita income.
Highest literacy rate for Afghanistan will also help Afghans in making peace possible.

\section{The Proposed Alphabets}

In this part, I propose Latinized alphabets for Pashto and Dari. Including the 26 ISO defined basic Latin alphabets, other sounds which are not present in current Latin alphabets will be defined by a modified form of some letters. The total numbers of alphabets for Pashto including diacritics in the Latinized script become 41 letters which, in the current Arabic script for Pashto, are 49 including the 4 diacritics. Dari alphabets make a set of 32 letters in the Latin including the diacritics while in Arabic script they are 35 including the diacritic Tashkil signs. That excludes various other signs like Tanwin, Tashdid etc currently present in the Persian orthography. In the below tables, I define the corresponding letters for Dari and Pashto. As we can see the number of letters has been decreased. This is a positive indication that will make reading and writing easy in the Latin script.

Table 1. Proposed Latin-Based Alphabets for Pashto.

\begin{tabular}{|c|c|c|c|c|c|c|c|c|c|c|c|c|c|c|c|c|c|c|c|c|c|}
\hline No & 1 & 2 & 3 & 4 & 5 & 6 & 7 & 8 & 9 & 10 & 11 & 12 & 13 & 14 & 15 & 16 & 17 & 18 & 19 & 20 & 21 \\
\hline Latin & $\mathrm{Aa}$ & $\bar{A} \bar{a}$ & $\mathrm{Bb}$ & $\dot{\vec{C}} \dot{\hat{c}}$ & $\mathrm{Dd}$ & đִ̣̣ & $\mathrm{Ee}$ & Әә & $\dot{\varepsilon} \dot{\varepsilon}$ & $\mathrm{Ff}$ & $\mathrm{Gg}$ & $\dot{\mathrm{G} g} \dot{g}$ & $\mathrm{Hh}$ & Ii & $\hat{I} \hat{\imath} \hat{\imath}$ & $\mathrm{Jj}$ & $\dot{\mathrm{J}} \dot{\mathrm{j}}$ & $\mathrm{Kk}$ & $\mathrm{Ll}$ & $\mathrm{Mm}$ & $\mathrm{Nn}$ \\
\hline Arabic & هَزبر & I آ & ب & $\dot{\tau}$ & د & $\rightarrow$ & ي & $\vdots$ & $\dot{\varepsilon}$ & ف & $s$ & 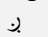 & $0 ، \tau$ & هزبْر & ي & ج & $j$ & ك، ق & J & 5 & ن \\
\hline No & 22 & 23 & 24 & 25 & 26 & 27 & 28 & 29 & 30 & 31 & 32 & 33 & 34 & 35 & 36 & 37 & 38 & 39 & 40 & 41 & 42 \\
\hline Latin & $\mathrm{N}_{0}$ & Oo & $\mathrm{Pp}$ & $\mathrm{Rr}$ & $I_{0} I I$ & Ss & $\dot{\dot{S}} \dot{\hat{s}}$ & $\dot{S} \dot{s}$ & $\mathrm{Tt}$ & Țt & $\tau \dot{\tau}$ & $E E$ & $\mathrm{Uu}$ & $\overline{\mathrm{U}} \overline{\mathrm{u}}$ & Ww & Yy & $\mathrm{Zz}$ & Żż & Ay ay & $\mathrm{Ai}$ ai & $\begin{array}{l}\text { Әi } \\
\text { əi }\end{array}$ \\
\hline Arabic & ن & و & 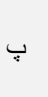 & J & d & ص، & ش & بن & $ت$ & ت & $\dot{\tau}$ & ج & هُ بيش & وو & 9 & ى & ذ & $\tau$ & ى & ئ & ى \\
\hline
\end{tabular}

Table 2. Proposed Latin-Based Alphabets for Dari (Afghan Persian).

\begin{tabular}{|c|c|c|c|c|c|c|c|c|c|c|c|c|c|c|c|c|c|c|c|c|}
\hline No & 1 & 2 & 3 & 4 & 5 & 6 & 7 & 8 & 9 & 10 & 11 & 12 & 13 & 14 & 15 & 16 & 17 & 18 & 19 & 20 \\
\hline Latin & $\mathrm{Aa}$ & $\bar{A} \bar{a}$ & $\mathrm{Bb}$ & $\mathrm{Dd}$ & $\mathrm{Ee}$ & $\dot{\varepsilon} \dot{\varepsilon}$ & $\mathrm{Ff}$ & $\mathrm{Gg}$ & $\mathrm{Hh}$ & Ii & Î $1 \hat{\imath}$ & $\mathrm{Jj}$ & $\ddot{\mathrm{J}} \dot{\mathrm{j}}$ & $\mathrm{Kk}$ & $\mathrm{Ll}$ & $\mathrm{Mm}$ & $\mathrm{Nn}$ & Oo & $\mathrm{Pp}$ & $\mathrm{Qq}$ \\
\hline Arabic & مَز زبر & I l & ب & د & ى & $\dot{\varepsilon}$ & ف & 3 & o. ح & ¡ز زبر & ي & ج & $j$ & $s$ & J & م & ن & g & 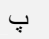 & ق \\
\hline No & 21 & 22 & 23 & 24 & 25 & 26 & 27 & 28 & 29 & 30 & 31 & 32 & & & & & & & & \\
\hline Latin & $\mathrm{Rr}$ & Ss & $\dot{\hat{S}} \dot{\hat{s}}$ & $\mathrm{Tt}$ & $\tau \dot{\tau}$ & $E E$ & $\mathrm{Uu}$ & $\bar{U} \bar{u}$ & Ww & Yy & $\mathrm{Zz}$ & $\mathrm{Ai}$ ai & & & & & & & & \\
\hline Arabic & $\jmath$ & س & ش & ت & $\dot{\tau}$ & ج & هُ بِيش & ؤ & و & ى & ذ، ز، ظ & ئ & & & & & & & & \\
\hline
\end{tabular}

Table 3. Pashto Text in New Latin Alphabets

\begin{tabular}{|c|c|}
\hline Paṣito in Rūmî Script & Pashto in Arabic Script \\
\hline Millî Surūd & ملي سرود \\
\hline Dā watan Afgèānistān day & دا وطن افغانستّان دى \\
\hline Dā izzat də har Aféān day & دا عزت د هر افغان دى \\
\hline Kor də sole kor də tūre & كور د سولي كور د نوري \\
\hline Har bazay ye kahramān day & هر بجى بي قهرمان دى \\
\hline Dā watan də tolo kor day & داوطن د ثتولو كور دى \\
\hline Də Baloc̈o, də uzbako & بلوخو د ازبكو \\
\hline Də Turkmano, Də Tājiko & ل د ن نركمنو د تاجكو \\
\hline Wərsara Arab Gūjar dî & ورسره عرب كوجر دي \\
\hline Pāmîrîyān, Nūristānyān & يامبريان نورستانيان \\
\hline Brāhawî dî, Kazalbāî̀ dî, & بر اهوى دي، قزلباش دي \\
\hline Hum Aymāk, hum pașaîyān & هم ايماق هم بشه ييان" \\
\hline Dā hewād ba təl żalegî̀ & دا هيو اد به تل خلييزي \\
\hline Laka ləmar pər ṡ̀n āsmān & لكه لَّر بز شنه آسمان \\
\hline Nūm də haq mo day rahbar & نوم د حق مو دى ر هبر \\
\hline Wāyū Allāho Akbar, Wāyū Allāho Akbar & و وايو الله اكبر، وايو الله اكبر \\
\hline
\end{tabular}


Table 4. Dari Text in New Latin Alphabets

\begin{tabular}{|c|c|}
\hline Darî in Rūmi Script & Dari in Arabic Script \\
\hline $\begin{array}{l}\text { Darîn watan, darîn zamino āsmān } \\
\text { Darîn diyāri mardżezi bāstān }\end{array}$ & درين وطن درين زمين و دريز آسمان \\
\hline Darîn fazā, darîn bihiš̀ti jāwedān & درين فضا درين بهشت جاودان \\
\hline Darîn zamān ba justujūi kārwān & درين زمان به جستجوى كاروان \\
\hline Ba justujūi kārwāni zindagî & به جستجوى كارو ان زندگى \\
\hline Ba sūyi awji bekarāni zindagî & بسوى اوج بيكر ان زندگى \\
\hline Ba ittifāqo bāhamî o yakdilî & به اتفاق و بآهمى و يكى دلى \\
\hline Rawānayem o merawem o merasem & روانه ايج و ميرويج و ميرسيج \\
\hline Ŝ̀uāri mā barādarî o bāhamî & شعار ما بر ادرى و باهمى \\
\hline Saādato nawāye sulhi dāyemî & سعادت و نواى صلح دايمى \\
\hline Salāmo amno ittihādo yak dilî & سلام و امن و اتحاد و يَكى دلى \\
\hline Barāye kāfai milal barābari & أ بر ایى كافه ملل بر ابرى \\
\hline Khamūŝ̀ bād zanghāye janghā & خموش باد زنگهاى جنـ ها \\
\hline Mabād zinda imtiyāzi rangha & مباد زنده امتياز رنـ ها \\
\hline Yakî șawed barādarāno đāharān & يكى شويد بر ادران و خو اهران \\
\hline Barādarāno đ̇āharān yakî s äwed & بر ادر ان و خو اهر ان يكى شويد \\
\hline
\end{tabular}

Table 5. Alphabets Used in Words

\begin{tabular}{|c|c|c|c|c|c|}
\hline No & Capital & Arabic Letters & Arabic Script & Latin Paṣ̆to & Latin Darî \\
\hline 1 & A a & أمَ زبر & سحر & Sahar & Sahar \\
\hline 2 & $\bar{A} \bar{a}$ & T، & آباد & $\bar{A} b \bar{a} d$ & $\bar{A} b \bar{a} \mathrm{~d}$ \\
\hline 3 & $\mathrm{~B} \mathrm{~b}$ & 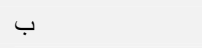 & بحرين & Bahrayn & Bahrayn \\
\hline 4 & $\dot{\overrightarrow{\mathrm{C}}} \dot{\mathrm{c}}$ & $\dot{\tau}$ & خادر & Ċādar & -- \\
\hline 5 & $\mathrm{Dd}$ & 2 & دلبر & Dilbar & Dilbar \\
\hline 6 & สุ ạ & 2 & ل & đ̦ol & -- \\
\hline 7 & $\mathrm{E} \mathrm{e}$ & ي & جامي ، براى & Jāme & Barāye \\
\hline 8 & Ә ә & $\dot{s}$ & نيرة & Terə & -- \\
\hline 9 & $\dot{\varepsilon} \dot{\varepsilon}$ & $\dot{\varepsilon}$ & | ( غ غم & $\dot{E} \mathrm{am}$ & $\dot{E} \mathrm{am}$ \\
\hline 10 & $\mathrm{Gg}$ & $s$ & كمان & Gumān & Gumān \\
\hline 11 & $\dot{\mathrm{G}} \dot{\mathrm{g}}$ & $\dot{2}$ & إنيره. & G̣ira & -- \\
\hline 12 & $\mathrm{Hh}$ & ( & هوا ، حلوه & Hawā, Halwā & Hawā, Halwā \\
\hline 13 & I i & وزبر & انتقام & Intikām & Intiqām \\
\hline 14 & Î î & ي & افغاني & Afėān̂̂ & Afčānî \\
\hline 15 & $\mathrm{Jj}$ & ج & جانان & Jānān & Jānān \\
\hline 16 & $\dot{\mathrm{J}} \hat{\mathrm{j}}$ & $j$ & ز زاله & J̄āla & J̄āla \\
\hline 17 & $\mathrm{~K} \mathrm{k}$ & ك، ق & كامياب، قدرت & Kāmyāb, kudrat & Kāmyāb \\
\hline 18 & $\mathrm{~L} 1$ & J & 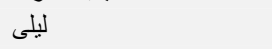 & Laylā & Laylā \\
\hline 19 & $\mathrm{M} \mathrm{m}$ & s & مرزا & Mirzā & Mirzā \\
\hline 20 & $\mathrm{~N} \mathrm{n}$ & ن & نغمه & Naغ̇ma & Naغ̇ma \\
\hline 21 & No n & ن & رنا & Rañā & -- \\
\hline 22 & $\mathrm{O} o$ & او & يكول & Pakol & Pakol \\
\hline 23 & $P p$ & 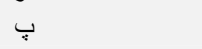 & بيغمبر & Payغ̇ambar & Payغ̇ambar \\
\hline 24 & $\mathrm{Qq}$ & ق & قدرت & -- & Qudrat \\
\hline 25 & $\mathrm{R} \mathrm{r}$ & ر & راحت & Rāhat & Rāhat \\
\hline 26 & I I I & $d$ & وريوند & Wı̊̆ūnd & -- \\
\hline 27 & S s & س & سردار & Sardār & Sardār \\
\hline 28 & $\dot{\hat{\mathrm{S}}} \dot{\mathrm{S}}$ & ش & شربت & Ṡarbat & Ṡarbat \\
\hline 29 & $\dot{S} \dot{s}$ & بن & يبنتو & Pașito & -- \\
\hline 30 & $\mathrm{Tt}$ & 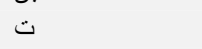 & تلاوت & Tilāwat & Tilāwat \\
\hline 31 & Țt ț & 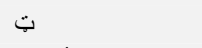 & تغغر & Ṭaċar & -- \\
\hline 32 & $\mathrm{Uu}$ & مُ ييش & كمرك & Gumruk & Gumruk \\
\hline 33 & $\tau \dot{\tau}$ & $\dot{\tau}$ & بلخ بلخ & Bali & Balí \\
\hline 34 & $E E$ & ₹ & جنار & Einār & Einār \\
\hline 35 & $\overline{\mathrm{U}} \overline{\mathrm{u}}$ & وُ & قارون & Kārūn & Qārūn \\
\hline 36 & $\mathrm{~W} w$ & 9 & وحدت & Wahdat & Wahdat \\
\hline 37 & Y y & ى، ي & يقين & Yaqîn & Yaqîn \\
\hline 38 & $\mathrm{Zz}$ & j & زيارت & Zyārat & Ziyārat \\
\hline 39 & Ż ż & $\dot{\tau}$ & خان & Żān & -- \\
\hline 41 & Ay ay & s & 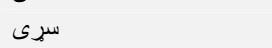 & Såray & -- \\
\hline 42 & $\mathrm{Ai}$ ai & ئ & جاويد كى ميرود؟ تاسو يـئ. & Taso yai & Jāwed Kai merawad. \\
\hline 43 & Әi əi & s & 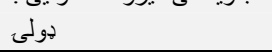 & ব̣oləi & - \\
\hline
\end{tabular}




\section{Challenges and Favorable Factors in Alphabet Switching}

In this part, I will discuss the challenges Afghanistan will face in switching the alphabets, in the light of a model for Romanization proposed in an article by İlker Aytürk published in Journal of World History. The model is focused on Social, Religious, Economic and Cultural factors favorable or otherwise, for Romanization of a Script in a country. Ayturk considers the failure or success of Romanization by dividing these factors into two categories; technical-infrastructural and the political-cultural factors. Below, I will discuss how favorable or otherwise, each factor seems when applied for possible Romanization in Afghanistan.

\subsection{Technical-Infrastructural Factors}

\subsubsection{Harmony between Dari and Pashto and the Roman Alphabet}

When it comes to the harmony of writing, the current Arabic script cannot fully incorporate the beauty of Dari and Pashto. The Abjad or consonantal nature of Arabic has made it difficult for these languages to fit in this script. Pashto and Dari both are vowel based languages and the Roman alphabets are the best options for choosing it as orthography which will solve the problems of vowel sounds and get rid of unnecessary confusion of reading and writing difficulty. The harmony between Pashto and Dari and the Roman alphabet could also be seen in the terms of the fact that, unlike Arabic which is a Semitic language, they belong to the EndoEuropean family of languages majority of which have adopted the Latin alphabets. Therefore, technically, based on this observation, the factor of Harmony is in favor of Dari and Pashto to switch to Latin, providing perfect economy of writing.

\subsubsection{Level of Literacy}

Ayturk puts that in order for a language to successfully switch to Latin script; low level of Literacy will act as a favorable factor facilitating the process of Romanization as fewer people will be negatively affected by the script change. Afghanistan, with its lowest literacy rate in the world, 38\% will experience a comparatively easy switch even though convincing the $38 \%$ population to switch alphabets itself is not an easy task. Among those literate, the majority of Afghans are familiar with the Latin alphabets. The low literacy rate of the Turkish population was one of the reasons for easy switching from Arabic to Latin script in 1929.

\subsubsection{Economic Cost}

In order for Romanization to be successful, its economic cost must be tolerable. The economic cost of the Romanization in Afghanistan can be estimated when the Government declares its intent to switch to the Latin script. As there are no estimations available at the moment, however, keeping the current economic conditions, the cost of Romanization in Afghanistan will be a difficult variable to deal with. However, the estimated opportunity cost of US\$ 0.10763 billion, the cost of illiteracy in Afghanistan, which is lost every year, could be a serious indication for Afghans to invest in Romanization. The cost could become tolerable through a slow Romanization process stretched through a long period of time. Apart from the opportunity costs, the employment opportunities arising from Transliteration, training the teachers in the new script, and the economic development that will follow by improved literacy due to the new script would also be of considerable weight.

\subsubsection{Past Experience of Script Change}

The Romanization of the script is seen as a big and vivid change, the trauma can be decreased to some extent by reference to such changes in the past. For instance, the switch from Cyrillic to Latin in the 1990s in Central Asian countries was facilitated by the fact that those countries had experienced the script change 3 times in hundred years. In the case of Afghanistan, the memory of the script change from Pahlavi script to Arabic for Persian and adopting the later script for Pashto is a tale of old ages and very fewer people know about it. Therefore, in relation to the past experience of script change, this variable seems unfavorable in case of Afghanistan. However, the example of script change in the neighboring Muslim countries of Central Asia, South East Asia; Malaysia, Indonesia, Brunei, Muslim countries of Africa, and Turkey can be of a positive role to overcome the trauma of script change in Afghanistan by referring to them.

\subsection{Political-Cultural Factors}

\subsubsection{Type of Regime}

For facilitating Romanization, the type of Government is of great importance. An authoritarian or totalitarian regime, as Ayturk puts it, can enforce script change by decree and silence opposition to it. In the case of Turkish, Mustafa Ataturk was considered more authoritarian than a democratic President. The concept of democracy was admired by him, as it is said, just in theory, and to his people, he was like a stern father and a strict teacher implementing his reforms by force and silencing oppositions. [36] Similar was the case in Central Asian countries under the rule of Lenin and Stalin.

When it comes to Afghanistan, the Government is democratic in nature and does not have much power of authority. The presence of Militant groups fighting against the Government in several parts of the country and the worst law and order situation have weakened Afghanistan's regime. The controversy over Electronic ID cards, for example, almost took a decade for Afghan parliament to solve it, yet the issue remained unsolved until Ashraf Ghani signed a decree calling for issuing the ID cards to Afghans. For the last few years, under Ashraf Ghani, a shift has been seen in centralizing the Government and enforcing the Constitution 
and Laws of Afghanistan. However, considering the nature of governance in Afghanistan, switching the alphabets does not seem an easy task.

\subsubsection{Canonical Texts}

Arabic script enjoys a great respect and religious significance in Afghanistan due to the fact that the Holy Quran is written in this script. The alphabets are taught at home by the parents of children or Madrassa-- religious school, from a very early age so they are able to learn the recitation of the Holy Quran and perform other religious duties in the Arabic language. The attachment of Afghans with Arabic alphabets is based on a very strong bond of religion which ties them with the rest of the Islamic nation. The Arabic language and script are seen as the language and alphabets of God thus giving it a sacred status. Apart from its sacred status, it also has a significant importance in terms of literature and nationalism. A wide range of Persian and Pashto literature has been written in this script. Therefore, the current script is looked upon both as religious as well as the national identity which will make it difficult to switch. However, Afghanistan, unlike Turkey and Central Asian countries, does not have to replace the Arabic script with Latin in every field. As we can conclude from the examples of these countries, Romanization started there as a political and religious reform. They wanted to abolish the Arabic script, removing it completely from the memory of their citizens to make them distant from the Islamic world. Turkey and Soviet Russia wanted to break the ties of their Muslims populations from the rest of Islamic world imposing a complete ban on Arabic text and publications. Even reading the previous books written in Arabic scripts was restricted to scholarly purposes only, for references. The use of Arabic script was prohibited even for religious purposes. Changing the script was just a small part of the goals of these countries to bring them out of their Islamic past. In the case of Afghanistan, switching the alphabets is not a political or cultural initiative rather we have to adopt Latin for the purpose of easy and improved literacy. An initiative simply based on the intent to have literate Afghans and a developed economy rather than making Afghans unlearn the Arabic script. This means to adopt Latin script for its implementation in educational and government sectors while the Arabic script for religious purposes as Afghans will still be able to learn, read and write it.

The use of Arabic Script for religious purposes will make it more valuable and respected as it will only be used in issues of faith rather than secular. For instance, when Arabic script is deemed as holy and sacred, there is no point in using it for secular texts. Muslims cannot touch the written text of the Holy Quran without performing certain obligations which include cleaning oneself by washing various parts of the body. How can one, then, justify the use of the alphabets of the Quran being used for secular, vulgar and unethical texts on social media and in written publication?

\section{Conclusion}

From the above explanations, one can easily conclude that the Current script is a misfit for Dari and Pashto which has resulted in widespread illiteracy, and thus, economic backwardness and the deteriorated security conditions in Afghanistan. Replacing the current orthographies for these languages with a new Latin Script for educational and administrative purposes will improve literacy, bring economic prosperity and play its part in making peace possible in Afghanistan, in particular, and in the region at large. Keeping the Arabic Script for religious purposes will help Afghanistan maintain its roots with its religion, and the rest of the Islamic world and with its rich literature and traditions.

\section{References}

[1] Ernst, C. W. (2013). "The Global Significance of Arabic Language and Literature". Religion Compass 7.

[2] Aydemir, Ş. S. (1995). Tek Adam Mustafa Kemal (19221938), Cilt III (12. basim).

[3] Tongul, N. (2004). Türk Harf İnk1lâb1. Ankara Üniversitesi Türk İnkılâp Tarihi Enstitüsü Atatürk Yolu Dergisi, 33/34, 103-130.

[4] Korkmaz, Z. (2009). Alfabe devriminin Türk toplumu üzerindeki sosyal ve kültüreletkileri. Turkish Studies, 4/3, 1469-1480.

[5] Milton-Edwards, B. (2005). Politics and religion. In Youssef M. Choueiri (Ed.), A companion to the history of the Middle East (pp.444-461). Oxford: Blackwell.

[6] Basak, O. (1986). Turkish language reform. In Renda, G., \& Kortepeter, C. M. (Eds.).

[7] Şimşir, B. N. (2006). Türk Harf Devrimi üzerine incelemeler. Ankara: Atam Yayınları.

[8] Davison, R. H. (1998). Turkey: A short history. Huntingdon: The Eothen Press.

[9] Lewis, G. (1999). The Turkish language reform: A catastrophic success. Oxford: Oxford University Press.

[10] Metz, H. C. (1996). Turkey: A country study. Washington, DC: Federal Research Division of the Library of Congress.

[11] Römer, C. (2009). Language and script. In G. Ágoston and B. Masters (Eds.), Encyclopedia of the Ottoman Empire (pp.322323). New York: Facts On File, Inc.

[12] Uzer, Umut (2016). An Intellectual History of Turkish Nationalism. Utah: The University of Utah Press. p. 103,104

[13] Aydemir, Ş. S. (1995). Tek Adam Mustafa Kemal (19221938), Cilt III (12. basim).

[14] Wood, Margaret M. "Latinizing the Turkish Alphabet: A Study in the Introduction of a Cultural Change." American Journal of Sociology, vol. 35, no. 2, 1929, pp. 194-203.

[15] Dogancay, S. A. (1995). An evaluation of the Turkish language reform after 60 years. Language Problems and Language Planning, 19(3), 221-249. 
[16] Smith. (n.d.). Language and Power in the Creation of the USSR, 1917-1953.

[17] Mark Sebba, Ideology and Alphabets in the former USSR, 2003, Department of Linguistics and Modern English Language.

[18] Uzman. (n.d.). Romanization in Uzbekistan Past and Present.

[19] Hegyi. (n.d.). "Minority and Restricted Uses of the Arabic Alphabet: The Aljamiado Phenomenon".

[20] Clement. (n.d.). Rewriting the "Nation": Turkmen Literacy, Language, and Power, 1904-2004.

[21] Boonlong, F. R. (2007). The Language Rights of the Malay Minority in Thailand." Asia-Pacific Journal on Human Rights $\&$ the Law 8 (1)"47-63.

[22] Baluch, B. \&. (1991). Visual word recognition in beginning readers of Persian. Perceptual and Motor.

[23] Akawi, E. (1943). Alefbaa Farouq: al-Hurouf al-Jadidah (Farouq Alphabet: the New Script). Cairo, c. Al Maaref.

[24] Haralambous, Yannis, Simplification of the Arabic Script: Three Different Approaches and their Implementations, Atelier Fluxus Virus 187, rue Nationale 59800 Lille, France

[25] Nammour, Yara Khoury, Fighting Illiteracy With Typography, Works That Work, issue 06

[26] Nammour, Y. K. (2014). Nasri Khattar, A Modernist Typotect (English and Arabic Edition).
[27] Shrivtiel, S. (1998). The Question of Romanisation of the Script and The Emergence of Nationalism in the Middle East. Mediterranean Language Review.

[28] Sakkal, M. (2000/2008). A Brief Survey of Proposals to Simplify Arabic Script.

[29] Al-Saggar, M. S. (1998). Abjadiat al Saggar, al mashrou' wal mihnah (The Saggar Alphabet, the project and the trial). Damascus, Beirut, Al Mada, Nicosia.

[30] Bianchi, R. M. (2012). 3arabizi - When local Arabic meets global English. Acta Linguistica Asiatica, 2(1), 89-100.

[31] Attwa, M. (2012). Arabizi: a writing variety worth learning? An exploratory study of the views of foreign learners of Arabic on Arabizi. (Unpublished master's thesis) Retrieved from

http://dar.aucegypt.edu/bitstream/handle/10526/3167/ThesisArabizi_is it a writing variety.

[32] UNESCO. (1953). The progress of Literacy in Various Countries. Paris: Firmen-Didot Et.

[33] Aytürk, İ. (2010). Script Charisma in Hebrew and Turkish: A Comparative. Framework for Explaining Success and Failure of Romanization.

[34] Literacy Statistics Metadata Information Table. UNESCO Institute for Statistics. September 2015

[35] World Literacy Foundation. (2015). The Economic \& Social Cost of Illiteracy. A snapshot of Illiteracy in a Global Context.

[36] Goldschmidt \& Davidson, 2006, p. 229. 